\title{
PERENCANAAN KEPERAWATAN DALAM MEMBERIKAN TINDAKAN ASUHAN KEPERAWATAN DI RUANG RAWAT INAP RUMAH SAKIT
}

\section{ANISYAH ISWARA}

\author{
anisyahiswara@gmail.com
}

\section{LATAR BELAKANG}

Proses keperawatan adalah suatu sistem yang mengatur perencanaan di dalam pelayanan kesehatan yang dimulai dari tahap pengkajian sampai tahap evaluasi yang dilakukan berdasarkan kaidah keperawatan. Salah satu tahap di dalam proses keperawatan adalah perencanaan keperawatan. Perencanaan keperawatan adalah penyusunan rencana tindakan keperawatan yang akan dilaksanakan untuk mengatasi masalah sesuai dengan diagnosa keperawatan yang telah ditentukan dengan tujuan terpenuhinya kebutuhan pasien. Perencanaan keperawatan adalah perumusan tujuan, tindakan, dan penilaian rangkaian asuhan keperawatan pada pasien/klien berdasarkan analisa pengkajian agar masalah kesehatan dan keperawatan pasien dapat diatasi . Perencanaan keperawatan dilakukan sebagai penentuan langkah-langkah didalam pemecahan masalah seperti perumusan tujuan, rencana tindakan, serta penilaian asuhan keperawatan yang telah dilakukan kepada pasien. Pengkajian keperawataan ini merupakan strategi untuk mencegah, mengurangi, dan mengkoreksi permasalahan yang telah diidentifikasi sebelumnya pada tahap diagnosa keperawatan.

Perencanan keperawatan disusun dan dirumuskan oleh perawat bersama keluarga atau orang terdekat pasien agar mecapai suatu keberhasilan dalam tindakan asuhan keperawatan, sehingga perawat perlu meningkatkan tindakan asuhan keperawatan, tindakan asuhan keperawatan dapat ditingkatkan dengan cara perawat harus mampu memberikan penjelasan kepada setiap pasien terkait perencanaan asuhan keperawatan agar keluarga atau orang terdekat pasien dapat diajak bekerja sama. Dalam melakukan pemberian tindakan asuhan keperawatan kepada pasien, perawat menempati sebagai posisi terdepan dari sitem pelayanan kesehatan di ruang rawat inap, karena perawat yang secara terus menerus menjaga pasin dan memantau keadaan pasien selama 24 jam di ruang rawat inap.Dengan demikian, perawat sangat berperan dalam peningkatan pelayanan mutu rumah sakit, maka apabila pemberian tindakan asuhan keperawatan tidak dilaksanakan dengan baik maka mutu pelayanan di ruang rawat inap rumah sakit menjadi kurang baik, sehingga perawat dapat memperhatikan langkah-langkah perencanaan keperawatan dalam pemberian tindakan asuhan keperawatan dan yang perlu ditingkatkan perawat dalam pemberian tindakan asuhan keperawatan ialah menentukan prioritas, apabila perawat sangat memperhatikan penentuan prioritas maka perawat dapat menentukan diagnose yang akan diambil pertama kali

Perencanaan keperawatan yang disusun perawat kepada pasien akan berbeda setiap pasiennya. Oleh karena itu, setap pasien di ruang rawat inap akan memiliki rencana keperawatan yang berbeda, meskipun berada di satu ruangan yang sama, karena tiap pasien dapat memiliki keluhan yang berbeda, perawat terlebih dahulu harus mampu untuk mengkaji keluhan yang ada ,menentukan diagnosa dan kemudian baru dapat menyusun perenanaan keperawatan 


\section{METODE}

Metode yang saya gunakan dalam membuat kajian ini dengan menggunakan metode kualitatif, maksudnya ialah dengan cara mengumpulkan beberapa data untuk dibaca,dianalisis,dan disimpulkan. Yaitu dengan cara sistem " Literature Review” ini dengan menganalisis yang berfokus tentang Perencanaan Keperawatan Dalam Memberikan Tindakan Asuhan Keperawatan Di Ruang Rawat Inap Rumah Sakit. Adapun tinjauan literature review yang digunakan dalam melakukan pengkajian perencaaan keperawatan dalam memberikan tindakan asuhan keperawatan di ruang rawat inap rumah sakit dapat menggunakan jurnal, google scholar, ,textbook, e- book, dan buku pedoman yang berkaitan dengan judul kajian tersebut. Jurnal dan referensi yang digunakan pada literature review ini dengan tahun terbit paling lama tahun 2012, dengan jumlah minimal 10 referensi literature, serta melakukan eksplorasi dan kajian bebas dengan menggunakan kata kunci perilaku perawat, penerapan kebijakan keselamatan dan kesehatan kerja. Sehingga jurnal, text book, google scholar dan e-book yang digunakan dalam pengkajian dapat digunakan untuk mengetahui bagaimanapengkajian perencaaan keperawatan dalam memberikan tindakan asuhan keperawatan di ruang rawat inap rumah sakit

\section{HASIL}

Hasil dari kajian dan perbandingan serta mengaanalisis dari berbagai literatur yang telah dibaca adalah perencanaan keperawatan memberikan tindakan asuhan keperawatan di ruang rawat inap rumah sakit. Perencanaan keperawatan adalah tindakan yang di rancang untuk membantu pasien dalam mengatasi masalah-masalah yang dimilikinya agar pasien dapat beralih dari tingkat kesehatan saat ini ke tingkat kesehatan yang diinginkan sesuai hasil yang diharapkan bersama dan penyusunan rencana keperawatan bekerjasama dengan keluarga. rencana keperawatan juga dikomunikasikan dengan tim kesehatan untuk meningkatkan pendekatan ketika bekerja sama dengan keluarga untuk mencapai hasil yang di harapkan. Keluarga berhak dan bertanggungjawab untuk membuat keputusan kesehatan mereka sendiri. Penempatan rencana asuhan keperawatan mengikuti pilihan bersama yang dirancang untuk mencapai tujuan yang telah ditetapkan. Salah satu dari perencanaan keperawatan yang disusun perawat pada ruang rawat inap adalah pemeriksaan tanda-tanda vital untuk mengetahui perubahan keadaan umum,monitor frekuensi, kedalaman napas dan bunyi napas tambahan pasien, memberi posisi semi fowler pada pasien yang membutuhkan, dan masih banyak contoh bentuk perencanaan keperawatan lainnya. 


\section{PEMBAHASAN}

\section{- Perencanaan Keperawatan}

Perencanaan keperawatan adalah pengembangan strategi desain untuk mencegah, mengurangi, dan mengatasi masalah- masalah yang telah diidentifikasi dalam diagnosis keperawatan. Desain perencanaan menggambarkan sejauh mana Anda mampu menetapkan cara menyelesaikan masalah dengan efektif dan efisien. Perencanaan keperawatan adalah perumusan tujuan, tindakan, dan penilaian rangkaian asuhan keperawatan pada pasien/klien berdasarkan analisa pengkajian agar masalah kesehatan dan keperawatan pasien dapat diatasi . Perencanaan keperawatan dilakukan sebagai penentuan langkah-langkah didalam pemecahan masalah seperti perumusan tujuan, rencana tindakan, serta penilaian asuhan keperawatan yang telah dilakukan kepada pasien. Tipe Rencana Tindakan Keperawatan terdiri dari:

\section{1) Diagnostik/Obserevasi}

Rencana tindakan keperawatan diagnostik adalah rencana tindakan untuk mengkaji atau melakukan observasi terhadap kemajuan klien dengan pemantauan secara langsung yang dilakukan secara berkesinambungan. Dengan observasi ini, diharapkan hal-hal yang perlu ditetapkan dalam kriteria hasil dapat dipantau secara berkesinambungan sampai tujuan berhasil dicapai.

\section{2) Terapeutik/Nursing Treatment}

Rencana tindakan keperawatan terpeutik adalah rencana tindakan yang ditetapkan untuk mengurangi, memperbaikidan mencegah perluasan masalah.Rencana tindakan ini berupa intervensi mandiri yang bersumber dari ilmu, kiat dan seni keperawatan. Dalam suatu masalah keperawatan, biasa didapatkan beberapa (lebih dari satu) alternatif penyelesaian masalahnya, dituntut untuk dapat memilih mana yang paling sesuai untuk ditetapkan pada pasien.

\section{3) Penyuluhan /Health Education/Pendidikan Kesehatan}

Rencana tindakan keperawatan yang berbentuk pendidikan kesehatan adalah rencana tindakan yang harus ditetapkan bertujuan untuk meningkatkan perawatan diri kilen dengan penekanan pada partisispasi klien untuk betanggung jawab terhadap perawatan diri, terutama untuk perawatan dirumah. Penyuluhan atau pendidikan kesehatan diperlukan, terutama bila masalah keperawatan dan kriteria hasil berhubungan dengan aspek kognitif, afektif, dan psikomotor. Penyuluhan yang Anda lakukan dapat berbentuk penyuluhan umum tentang segala sesuatu tentang penyakit dan perawatan klien atau juga lebih spesifik sesuai dengan masalah yang terjadi 
4) Rujukan atau Kolaborasi atau Medical Treatment

Rencana tindakan keperawatan kolaboratif adalah tindakan medis yang dilimpahkan kepada perawat . Rencana kolaboratif ini disesuaikan dengan masalah yang terjadi. Masalah yang bersifat kognitif, afektifdan psikomotor mungkin tidak memerlukan tindakan medis. Namun, untuk masalah yang berhubungan dengan perubahan fungsi tubuh, sering memerlukan rencana kolaboratif.

\section{5) Intervensi keperawatan atau pelaksanaan keperawatan}

Intervensi keperawatan atau pelaksanaan keperawatan Intervensi keperawatan atau pelaksanaan keperawatan adalah realisasi rencana tindakan untuk mencapai tujuan yang telah seorang perawat tetapkan. Kegiatan dalam pelaksanaan juga meliputi pengumpulan data berkelanjutan, mengobservasi respon klien selama dan sesudah pelaksaan tindakan, serta menilai data yang baru. Intervensi keperawatan dibuat untuk mencapai tujuan dan kriteria hasil yang diharapkan guna mengatasi etiologi dan menyelesaikan masalah keperawatan. Intervensi dibuat secara spesifik dan operasional yang terdiri dari aktivitas apa yang akan dilakukan, bagaimana, seberapa sering, dan lebih baik lagi jika teridentifikasi siapa apa yang melakukan. prinsip tersebut perlu dilakukan supaya tiap perawat yang melihat perencanaan keperawatan mudah untuk melakukannya atau mengaplikasikan rencana tersebut. setelah tindakan telah dilakukan, tiap intervensi dievaluasi berdasarkan respon pasien terhadap tindakan yang telah diimplementasikan dan mengacu atau berorientasi pada kriteria hasil yang telah ditetapkan (Abdelkader, Othman, 2017)

\section{6) Evaluasi Keperawatan}

Pengertian Evaluasi adalah penilaian dengan cara membandingkan perubahan keadaan pasien (hasil yang diamati) dengan tujuan dan kriteria hasil yang Anda buat pada tahap perencanaan. Tujuan diadakan rencana tindakan keperawatan, untuk memodifikasi rencana tindakan keperawatan serta meneruskan rencana tindakan keperawatan. Evaluasi pada dasarnya dilakukan untuk mengetahui apakah tujuan yang ditetapkan sudah dicapai atau belum. Oleh karena itu, evaluasi dilakukan sesuai dengan kerangka waktu penetapan tujuan (evaluasi hasil), tetapi selama proses pencapaian terjadi pada klien juga harus selalu harus dipantau untuk memudahkan mengevaluasiatau memantau perkembangan klien, digunakan komponen SOAP/ SOAPIE/SOAPIER. 
- Perencanaan Keperawatan Dalam Memberikan Tindakan Asuhan Keperawatan Di Ruang Rawat Inap Rumah Sakit

Perencanaan keperawatan dalam memberikan tindakan asuhan keperawatan di ruang rawat inap rumah sakit harus dibuat secara spesifik, jelas, jangka waktu ditentukan, dapat diukur baik kognitif, afektif, dan psikomotor. Jenis intervensi keperawatan harus mencantumkan therapi keperawatan, pendidikan kesehatan, kolaborasi dengan Tim kesehatan lain, observasi dan monitoring. Perencanaan keperawatan dalam memberikan tindakan asuhan keperawatan di ruang rawat inap rumah sakit harus mempunyai perencanaan waktu di dalam melakukan tindakannya. Adanya perencanaan waktu dibutuhkan untuk mencapai tujuan awal yang telah ditetapkan, mendisiplinkan diri perawat, dapat berpikir kritis dan dapat meningkatkan tingkat keberhasilan asuhan keperawatan. Pada ruangan rawat inap, perawat yang bertugas harus terlihat selalu siap akan perubahan kondisi pasien atau jika ada informasi baru. Dengan mempunyai perencanaan waktu yang ideal, perawat dapat mengambil dan memperkirakan suatu keputusan dengan baik dan efektif.

\section{PENUTUP}

Berdasarkan hasil dari kajian ini, dapat disimpulkan bahwa perencanaan keperawatan Perencanaan keperawatanmempunyai peranan penting didalam memberikan tindakan asuhan keperawatan di ruang rawat inap rumah sakit . Perencanaan keperawatan adalah Perencanaan keperawatan adalah penyusunan rencana tindakan keperawatan yang akan dilaksanakan untuk mengatasi masalah sesuai dengan diagnosa keperawatan yang telah ditentukan dengan tujuan terpenuhinya kebutuhan pasien. Perencanaan keperawatan adalah perumusan tujuan, tindakan, dan penilaian rangkaian asuhan keperawatan pada pasien/klien berdasarkan analisa pengkajian agar masalah kesehatan dan keperawatan pasien dapat diatasi

Proses asuhan keperawatan merupakan tugas dan kewajiban seorang perawat dari pasien datang sampai pasien pulang dimulai dengan pengkajian secara menyeluruh, kemudian menegakkan diagnosa keperawatan dari data pengkajian tersebut, serta melaksanakan intervensi, implementasi dan evaluasi keefektifan diagnosa awal yang sudah ditegakkan (Nursalam, 2007). 


\section{DAFTAR PUSTAKA}

1. Butar-Butar, J., \& Simamora, R. H. (2016). Hubungan Mutu Pelayanan Keperawatan dengan Tingkat Kepuasan Pasien Rawat Inap di RSUD Pandan Kabupaten Tapanuli Tengah. Jurnal Ners Indonesia, 6(1), 50-63.

2. Simamora, R. H. (2005). Hubungan Persepsi Perawat Pelaksana Terhadap Penerapan Fungsi Pengorganisasian Yang Dilakukan Oleh Kepala Ruangan Dengan Kinerjanya Diruang Rawat Inap RSUD Koja Jakarta Utara (Doctoral dissertation, Tesis FIK UI, Tidak dipublikasikan).

3. Yusuf, M., (2013). Hubungan Manajemen Waktu Perawat Pelaksana Dengan Pendokumentasian Asuhan Keperawatan di Ruang Rawat Inap Kelas III Rumah Sakit Umum Daerah Dr. Zainoel Abidin Tahun 2013. Jurnal Ilmu Keperawatan, 1(1), 76-84.

4. Nogo, A. (2014). Kinerja Perawat Dalam Penerapan Standar Asuhan Keperawatan di Rumah Sakit Umum Daerah Naibonat Kabupaten Kupang. Jurnal Penelitian, 18, 62-66.

5. Rosdahl, B. C. \& Kowalski, T. M. (2014). Buku Ajar Keperawatan Dasar. Ed.10.Vol 1. Jakarta: EGC.

6. Kozier, Barbara. (2010). Buku Ajar Fundamental Keperawatan; Konsep, Proses dan Praktik edisi 7 Volume. Jakarta: EGC

7. Syamsudin, (2004). Hubungan penerapan standar asuhan keperawatan dengan kepuasan pasien terhadap pelayanan keperawatan diruang rawat inap RSU PKU Muhammadiyah Yogyakarta.Thesis (Publikasi): Universitas Diponegoro. Di diakses pada tanggal 16 juli 2016 dariwww. eprints.undip.ac.id.

8. Sumijatun, (2010). Konsep Dasar Menuju Keperawatan Profesional. Jakarta: Trans Info Media. 
9. Siahaan, J. V., Siagian, A., \& Bukit, E. K. (2018). Pengaruh pelatihan ronde keperawatan terhadap kinerja perawat dalam asuhan keperawatan di rs royal prima medan. Jumantik (Jurnal Ilmiah Penelitian Kesehatan), 3(1), 1-15.

10. Hidayat, A. A. A. (2011). Pengantar Konsep Dasar Keperawatan. Ed. 2. Jakarta: Salemba Medika

11. Potter, P. A \&Perry, A. G. (2005). Buku Ajar Fundamental Keperawatan.Jakarta: EGC. 